\title{
WORKING EFFICIENCY AND IMPEDIMENTS FACED BY PRODUCTION LABOUR IN MEDIUM SIZED KNITWEAR UNITS OF LUDHIANA
}

\author{
SURABHI MAHAJAN, HARMINDER SAINI \& AMANPREET KAUR
}

Department of Apparel and Textile Science, College of Home Science, PAU, Ludhiana, India

\begin{abstract}
The knitwear industry plays a significant role in the economies of the majority of the countries. The Indian knitting industry is one of the most innovative global producers of knitwear. Ludhiana Knitwear Cluster had been significant due to its vast production capacity and contribution to the economy and export market as well. Human capital forms an integral part of the industry and almost all industries gamble on this essential element to attain success. The present study made an effort to study the working efficiency of the production labour and impediments faced by them. Eight medium sized knitwear units of Ludhiana were surveyed. The data obtained from 120 respondents elucidates that the working efficiency of the labour was low to moderate because of lack of technical skills and training. Common problems identified in majority production workers were lack of training, incentives, less remuneration and uncomfortable working aids. Based on the results of collecting data it is inferred that need based trainings and a minimum educational background are mandatory for increasing working efficiency amongst production labour.
\end{abstract}

KEYWORDS: Knitwear, Productive Workforce, Skill Gaps \& Working Efficiency

Received: Aug 18, 2017; Accepted: Sep 08, 2017; Published: Oct 03, 2017; Paper Id.: IJSMMRDOCT20172

\section{INTRODUCTION}

Ludhiana in Punjab is called the 'Manchester' of India as far as knitwear is concerned (Anonymous 2017). The knitwear industry has a range of firms with different investments in plant and machinery. Lohana (2014) stated that, the needs, problems and potentials of these enterprises differ not just with the nature of activity, but also with the size, geographical location and structure whether it is organized or unorganized. The medium sized industries are the ones whose investment in plant and machinery is more than five crore rupees but does not exceed ten crores (Jaswal 2010). Small and medium enterprises (MSMEs) are the backbone of Indian economy. They provide immediate large-scale employment, ensure a more equitable distribution of the national income, and facilitate effective mobilization of resources, both capital and labour, which might otherwise remain unutilized (Lohana 2014). The Ludhiana industry is facing government's anti-friendly policies, high rate of taxation, costly power, scarcity of labour and delay in refunds leading to the downfall of the industry (Mander 2015). The labour is mostly untrained and migratory increasing the complications for the industry owners and it is one of the crucial problems faced by the industry. The labour problems have left the knitwear industry in Ludhiana to operate only around 60 per cent of its capacity (Beiler et al 2008). To manufacture a vast range of products in a knitwear unit, trained workforce is required. Development does not start with goods; it starts with 'people' and their education, 'organizing' and 'discipline' (Schumacher 2001).

Organizational performance is linked to effectiveness, efficiency, quality and productivity of workers and to achieve better productivity, skilled, educated and efficient workforce are required who can do multi tasking 
(Rowlinson and Proctor 1999). Ogunniyi (1985) is of the view that, an employee cans works more effectively if training equips workers with the knowledge and skill to do their present jobs, including foreseeable development within the jobs, while development equips staff by the growth of their potentials for higher responsibilities in future. Training is a highly skilled and professional activity which helps in improving the overall performance of the organization as expressed by Premi (1997). In the success of any organization, worker's efficiency plays a crucial role besides technology upgradation that can be increased by education and training of the staff. In general, different forms of monetary incentives are intended to increase employee effort which increases employee performance, productivity and efficiency (Bonner and Sprinkle, 2002). To make workers more efficient, training and development are assumed to have a very positive effect in any growing organization and need based training can only be implemented if the existing skill sets and the gaps are known to the promoters of the industries (Shanmugasundaram 2011). Indian industry needs to improve its performance on productivity, quality and lead-time and technology upgradation to be able to compete successfully in the global marketplace. At present, modern technologies require fully skilled and efficient workers for operation and maintenance. Therefore, it is necessary to increase the efficiency of production labour through training and retraining (Kucharcikova 2011). Hence, the present study has been planned to assess the working efficiency and impediments faced by a production workforce of selected knitwear units and suggest ways for increasing their work efficiency.

\section{METHODOLOGY}

For conducting the research, a structured interview schedule was designed to investigate the working efficiency of production labour. A critical review of literature along with personal experience was used to construct the schedule. The study was carried out in eight medium sized knitwear units of Ludhiana city, which were selected randomly. All the respondents were personally interviewed to increase the reliability and validity of the information. The identity of the selected units has not been revealed on their request. A total of 120 respondents (15 from each industry) were purposively selected on the recommendation of the respective Production Managers and their permanent job profile. The data regarding their quantitative and qualitative efficiencies were collected and analyzed.

\section{RESULTS}

The results regarding production labour's socio-personal background, educational and vocational qualification, work profile, employment conditions and working efficiency are summarized below.

Table 1: Socio-Personal Background of the Respondents

\begin{tabular}{|c|l|c|c|}
\hline \multirow{2}{*}{ S. No } & \multirow{2}{*}{ General Profile } & \multicolumn{2}{|c|}{ Respondents } \\
\cline { 3 - 4 } & & $\mathbf{f}$ & $\%$ \\
\hline 1. & Age (Years) & & \\
\hline & $15-24$ & 15 & 12.5 \\
\hline & $25-34$ & 52 & 43.3 \\
\hline & $35-44$ & 35 & 29.2 \\
\hline & 45 and above & 18 & 15.0 \\
\hline $\mathbf{2 .}$ & Gender & & \\
\hline & Male & 120 & 100.0 \\
\hline 3. & Marital Status & & \\
\hline & Married & 94 & 78.3 \\
\hline & Unmarried & 26 & 21.7 \\
\hline
\end{tabular}

After analyzing the data, it was observed that 43.3 per cent of the respondents were between $25-34$ years of age 
group, whereas merely 12.5 per cent falls between the age group of 15-24 years and the reason behind this is that the companies prefer to employ experienced workers. The data also revealed that all the respondents were male and mostly $(78.3 \%)$ married.

Table 2: Qualification of the Respondents

\begin{tabular}{|c|c|c|c|}
\hline \multirow{2}{*}{ S. No. } & \multirow{2}{*}{ Particulars } & \multicolumn{2}{|c|}{ Respondents } \\
\hline & & $\mathbf{f}$ & $\%$ \\
\hline \multirow[t]{6}{*}{1.} & Educational Qualification & & \\
\hline & Uneducated & 10 & 8.3 \\
\hline & Primary & 52 & 43.3 \\
\hline & Matriculate & 35 & 29.2 \\
\hline & Intermediate & 21 & 17.5 \\
\hline & Graduate & 2 & 1.7 \\
\hline \multirow[t]{3}{*}{2.} & Vocational Qualification & & \\
\hline & Yes & 2 & 1.7 \\
\hline & No & 118 & 98.3 \\
\hline \multirow[t]{4}{*}{3.} & Experience (Years) & & \\
\hline & $1-5$ & 32 & 26.7 \\
\hline & $6-10$ & 39 & 32.5 \\
\hline & More than 10 & 49 & 40.8 \\
\hline
\end{tabular}

It was found that 43.3 per cent of the respondents had primary education and a very few of them were graduates. Workers with formal training or vocational qualification comprised of only $1.7 \%$ of the production labour, although they were working as permanent employees of the selected units. The collected data also indicated that 40.8 per cent of the workers had more than 10 years of experience which makes it clear that companies hire experienced workers regardless of their academic and vocational qualification.

Table 3: Work Profile of the Respondents

\begin{tabular}{|c|l|c|c|}
\hline \multirow{2}{*}{ S. No. } & \multicolumn{1}{|c|}{ Work Profile } & \multicolumn{2}{|c|}{ Respondents } \\
\cline { 3 - 4 } & & $\mathbf{f}$ & $\mathbf{\%}$ \\
\hline $\mathbf{1 .}$ & Garment Assembly Section & & \\
\hline & Complete garment & 21 & 17.5 \\
\hline & Over locking & 19 & 15.8 \\
\hline & Tailoring/Sewing & 80 & 66.7 \\
\hline $\mathbf{2 .}$ & Type of work in tailoring/sewing & & \\
\hline & Shoulder joining & 7 & 8.7 \\
\hline & Placket making & 31 & 38.8 \\
\hline & Collar attachment & 23 & 28.7 \\
\hline & Neck tape attachment & 9 & 11.2 \\
\hline & Pocket attachment & 10 & 12.6 \\
\hline
\end{tabular}

$\mathbf{n}=\mathbf{1 2 0}$

The knitwear could be classified into three main areas, namely: pre-sewing, sewing and post-sewing operations. The production of apparel is a labour intensive operation, especially at the assembly (sewing) stage and basic single needle machines used in sewing are versatile and need highly skilled tailors to stitch the garments. Data indicates that 66.7 per cent of the workers were from a tailoring section of the production department. In tailoing/sewing section, 38.8 per cent of the workers were involved in placket making whereas 28.7 per cent were involved in collar attachment. Only 8.7 per cent of the workers were involved in the shoulder joining section. 
Table 4: Working Efficiency of the Respondents

\begin{tabular}{|c|c|c|c|}
\hline \multirow{2}{*}{ S. No. } & \multirow{2}{*}{ Particulars } & \multicolumn{2}{|c|}{ Respondents } \\
\hline & & f & $\%$ \\
\hline \multirow{3}{*}{1.} & Self understanding of the work & & \\
\hline & Yes & 47 & 39.2 \\
\hline & No & 73 & 60.8 \\
\hline \multirow[t]{3}{*}{2.} & $\begin{array}{l}\text { Ability to match the design specifications given by the } \\
\text { supervisor }\end{array}$ & & \\
\hline & Always & 50 & 41.7 \\
\hline & Most of the times & 70 & 58.3 \\
\hline \multirow[t]{5}{*}{3.} & Requirement of extra time to complete the assigned task & & \\
\hline & Always & 31 & 25.8 \\
\hline & Most of the times & 63 & 52.5 \\
\hline & Sometimes & 17 & 14.2 \\
\hline & Never & 9 & 7.5 \\
\hline \multirow[t]{5}{*}{4.} & $\begin{array}{l}\text { Number of times work has to be repeated due to some } \\
\text { alterations }\end{array}$ & & \\
\hline & 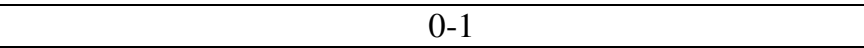 & 23 & 19.2 \\
\hline & $1-2$ & 51 & 42.5 \\
\hline & $2-3$ & 32 & 26.7 \\
\hline & $3-4$ & 14 & 11.7 \\
\hline \multirow[t]{3}{*}{5.} & $\begin{array}{l}\text { Ability to work on more advanced and computer assisted } \\
\text { machines }\end{array}$ & & \\
\hline & Yes & 21 & 17.5 \\
\hline & No & 99 & 82.5 \\
\hline \multirow[t]{3}{*}{6.} & Ability to repair small break downs in machines & & \\
\hline & Yes & 55 & 45.8 \\
\hline & No & 65 & 54.2 \\
\hline \multirow[t]{3}{*}{7.} & $\begin{array}{l}\text { Ability to communicate their problems with senior } \\
\text { authority }\end{array}$ & & \\
\hline & Yes & 48 & 40.0 \\
\hline & No & 72 & 60.0 \\
\hline
\end{tabular}

It was observed from the data that 60.8 percent of the workers had no self understanding of the work. Nearly 58 percent of the workers were able to match the design specifications frequently given by the supervisor. The majority of the respondents $(52.5 \%)$ was not able to finish their work on time and required extra hours to complete their work.

Knitwear industries use endless varieties of yarns and other raw materials to be converted into various types of garments. All these variations create a need for specialized machines or modifications in the existing machines. Due to this many knitwear companies are attempting to use modern technology for improving productivity. Amongst the selected workers, it was observed that a very few number (17.5 per cent) of production labour was able to work on more advanced, automated and computer assisted machines. A large number (54.2\%) of the workers were not able to repair small breakdowns in machines. The data also indicated that the majority of the workers have to repeat their work once, twice or thrice to make alterations in tailoring.

It is clear from the data that the majority of the respondents (60 per cent) were not able to communicate their problems or issues with the senior authority due to which they waste a lot of time in solving their problems themselves. 
Table 5: Major Problems Faced by Production Workers

\begin{tabular}{|l|c|c|c|}
\hline \multicolumn{1}{|c|}{ Problems } & Score & WMS & Rank \\
\hline No training & 294 & 2.45 & 1 \\
\hline No incentive & 150 & 1.25 & 2 \\
\hline Non-availability of line supervisors & 3 & 0.03 & 6 \\
\hline Less remuneration & 68 & 0.60 & 3 \\
\hline Frequent machine breakdowns & 14 & 0.12 & 5 \\
\hline Uncomfortable working aids & 42 & 0.35 & 4 \\
\hline
\end{tabular}

$\mathbf{n}=\mathbf{1 2 0}$

WMS $=$ Weighted Mean Score

Table 5 elucidates the distribution of workers towards different impediments affecting their working efficiency. It was observed that lack of training was given a first rank with WMS 2.45 and second rank was given to no incentives for their best performance with WMS 1.25. Less remuneration and uncomfortable working aids were given third and fourth rank with WMS 0.60 and 0.35 respectively.

\section{Gap Areas}

During the analysis of data, it was observed that certain gap areas existed between the production expected and actual production taking place in different industries. An attempt was made to find out the reasons for these gaps and they are listed as follows:

- Unskilled labour as the majority of the workers had no vocational qualification and had education only till primary level.

- Lack of time management amongst workers due to which work was not finished in an allotted time period.

- Workers lacked self understanding of the assigned work and every small thing has to be explained to them leading to time wastage.

- Workers were not able to do multitasking because they were tuned to chain system of production.

- Workers had to repeat their work due to minor alterations which ultimately affects their working efficiency and fulfillment of lead times.

- Workers were not quality conscious so frequent repetition of work was required.

- The majority of the workers had little understanding to repair the small breakdowns in machines owing to interruptions in smooth work flow.

\section{Suggestions for Improving Work Efficiency}

Based on the findings of the study, certain recommendations were made to the Production Managers for improving work efficiency of production workers. These are as follows:

- All workers should be at least matriculate as it lays the foundation of understanding of the given instructions.

- Workers should possess a diploma or certificate course in their field of specialization as it is an essential prerequisite for further skill development and also ensures basic knowledge for various work profiles. 
- Regular training should be impacted by the industry or any third party for teaching time management and multitasking to productive labour.

- The industries can also think upon adding incentive or bonus scheme to motivate workers to be time and work efficiently.

- Skill upgradation of workers should be a mandate for industry as well as personal responsibility of the workers and remuneration to be linked with it.

- Working efficiency should be monitored and gap areas should be identified regularly to impart need based training.

\section{CONCLUSIONS}

The major findings of the study revealed that maximum number of respondents had completed only primary education followed by matriculates. There were only two members in the total production workforce with formal training before they got employed. The majority of the workers were from sewing department. They had to repeat their work due to imperfections like skipped stitches, improper stitching of placket, uneven stitch length, etc. More than fifty percent of the workers demand extra time to finish the work assigned to them and approximately 61per cent workers always needed guidance from the designers or line supervisors to understand the new designs. There was not even a single worker who was able to work on advanced computer aided machinery and majority lacked the technical knowledge to repair small breakdowns. Furthermore, 60 per cent of the production workforce was not able to share the difficulties or obstacles they face in the production processes to their seniors. Thus, training is required in knitwear industries to address to all the above mentioned areas which affect the working efficiency of the labour. Major problems identified in production labour include lack of incentives, less remuneration and no trainings at all. Specific technical skills, self understanding of work and motivation to perform better are the important skill gaps found in production labour in medium sized knitwear units of Ludhiana.

\section{REFERENCES}

1. Beiler A, Lindberg I and Pillay D, Labour and the Challenges of Globalization: What Prospectus for Transational Solidarity? (Pluto Press, London) 2008, 11-12.

2. Bonner, S.E. and Sprinkle, G.B., 'The Effects of Monetary Incentives on Effort and Task Performance: Theories, Evidence, and a Framework for Research', Accounting, Organizations \& Society 2002, 303-345.

3. Cole G A, Management Theory and Practice. (DP Publication Ltd. London) 1991, 40-41.

4. Jaswal A, Micro, Small and Medium Enterprises Development Act, 2006 (Law, Policies and Incentives. (Bharat Law House Pvt. Ltd. New Delhi) 2010, 86.

5. Kucharcikova, Human Capital - Definition and Approaches, JHR Mgt \& Erg, 5(2011) 203-205.

6. Lohana S, Micro, Small and Medium Enterprises (MSMEs) for Inclusive Growth (New Century Publications, New Delhi) 2014, 3-4.

7. Mander M, A bumpy ride for state's industrial hub (Tribune News Service, Ludhiana) 2015, 2.

8. Ogunniyi O, Practical Guide to Staff Performance Appraisal (Folio Nigeria Co. Ltd., New Delhi) 1985, 3. 
9. Premi, G D, HRD-Correct Methodology and Training, Clothesline, 1997, 90-91.

10. Rowlinson, M., and Proctor, S. Organizational Culture and Business History. Organization Studies 3(1999) 369-96.

11. Schumacher. E F, Cited in Knowledge worker's hold key of garment industry's future by Ramaswamy. The Ind Tex J (2001) 133-35.

12. Shanmugasundaram S and Panchanatham N, Embracing Manpower for Productivity in Apparel Industry. Int J Innovation, Mgt \& Tech 2(2011) 232.

13. http://www.onlineclothingstudy.com/2011/12/how-to-grade-sewing-operators.html (accessed on 15.4.2017).

14. http://www.duerkopp-adler.com/en/main/applications/menswear/12A/, (accessed on 22.4.2017). 
